\title{
Formation of Entrepreneurial Skills in Students in a Changing World
}

\author{
Maryna Salun ${ }^{1}$, Kateryna Zaslavska ${ }^{2}$, Radka Vaníčkováa $^{3,}$, Kristýna Šindelková3 \\ ${ }^{1}$ Simon Kuznets Kharkiv National University of Economics, Economy and Law Faculty, Nauky avenu 9a, 61001 Kharkiv, \\ Ukraine \\ ${ }^{2}$ Simon Kuznets Kharkiv National University of Economics, Management and Marketing Faculty, Nauky avenue 9a, 61001 \\ Kharkiv, Ukraine \\ ${ }^{3}$ Institute of Technology and Business, Faculty of Corporate Strategy, Department of Management, Nemanická 536/7, 370 01 \\ České Budějovice, Czech Republic
}

\begin{abstract}
In today's global world, a number of concepts exist for the typology of a manager's personality. The personality of a manager is evident through their daily practical actions and the degree of validity thereof. The entrepreneurial skills of students is related to whether they view entrepreneurship as a career alternative. The purpose of educating successful managers is to enable them to apply and implement the principles of managerial skills in business practice. This includes the fulfilment of managerial roles and the use of basic tools to accomplish this, the principles of coaching, the creation and effective management of work teams, and knowledge of HRM techniques such as brainstorming. The aforementioned is based on the assumption that the desired result can be effectuated by one factor, but also by a combination of several factors. Qualitative comparative analysis (QCA) was therefore applied to the demands for entrepreneurial skills on the labour market and the presence of this issue in the curricula of Ukrainian universities.
\end{abstract}

Keywords: entrepreneurial hard skills; entrepreneurial soft skills; entrepreneurial competencies; entrepreneurial education; start-ups.

\section{Introduction}

There are four basic typologies of a manager's personality, namely analytical, pragmatic, extrovert, and social. The social personality of a manager is focused on wellbeing and good relationships, whereby the manager can empathize with the situation and feelings of subordinate employees. A social manager does not like to listen to criticism or unpleasant things. However, they are very loyal and tend to help other employees. The analytical personality of a manager is focused on details, recognizing and continually assessing things. They require work to be carried out carefully, not only by and for himself, but also by and for his co-workers, for which clear and strict rules apply and must be observed. In contrast, the pragmatic personality of a manager is focused on performance, whereby the focus is on finding solutions to complex and challenging situations or tasks. Pragmatic managers usually derive satisfaction from achieving success. In practice, the manager is not only strict on themselves, but also with others and knows exactly what goals they want to achieve. The extrovert personality of a manager is focused on experience, which stems from excitement, fantasy and imagination. An extrovert manager does not like to strictly follow set standards and rules. They like to present their ideas here and now, while extensive and boring interpretations lack essence and represent a waste of time for them.

Leadership skills, as well as other abilities and skills, need to be acquired through practice and hard work [1]. However, there are many different ways to be a good manager-leader [2]. Many managers use different management styles [3]. The most appropriate management style is management that is flexible, adaptive, applicable to the circumstances, as different situations require different management methods. The leader must also trust the vision in every situation. The difference between a manager and a true leader lies in the following practical experience: a manager orders, a leader leads; a manager explains, a leader inspires; a manager requires discipline, a leader mentors; a manager delegates tasks, a leader delegates authority; a manager is above a team, a leader is part of a team.

Universities are critical for developing the levels of motivation and capabilities of graduates to effectively engage in entrepreneurial activity [4]. For this, students require a set of professional knowledge, especially

\footnotetext{
* Corresponding author: vanickovaradka@gmail.com
} 
practical skills in the field of management and decision-making, differentiated according to three basic levels of management, namely top, tactical and operational, which are crucial for fulfilling defined corporate goals. They also need to learn the basic typologies, functions and roles of managers, and management styles [5].

The concept of competence sometimes refers to competencies as a result (what is done) and sometimes as a process (how it is done) [6]. In our opinion, an integrated approach that emphasises personal attributes, delivered performance and context [7] fully describes the essence of competencies. It is defined as a set of knowledge, skills and attitudes necessary to exercise a given activity, but also the person's performance in a given context in terms of behaviours used at work and the subsequent achievements. The main constituents of competence are knowledge, skills and attitudes [8], whereby it is quite important to have synergy between them.

Entrepreneurial skills, practices and approaches are undergoing profound changes at present, which must be taken into account when shaping students' learning trajectories. For example, the dynamic development of startups in the field of social entrepreneurship necessitates the formation of knowledge about the development of society; such knowledge becomes vital to ensure the professional significance of entrepreneurship. At the same time, the most relevant professional skills of an entrepreneur remain verbal and written communication skills to create sustainable entrepreneurial connections and communities.

The modern Ukrainian start-up market [9] is characterized by rapid growth in the total costs of offers (on average $+40.19 \%$ annually); a doubling of the number of projects invested in and their average costs over a three year period; intensification of mergers and acquisitions ( $91.18 \%$ in the total structure); allocation and gradual growth of investments at the stage of supporting an innovative idea; stabilization of investment volumes at the initial stage of project formation and the stage of development of an innovative product; activation of the start-up movement at universities with the formation of project start-up teams and the involvement of consultants from the academic environment.

The current entrepreneurship training initiative, "The Entrepreneurship University", implemented by the network of YEP start-up incubators in cooperation with the Ministry of Education and Science of Ukraine, the Ministry for the Digital Transformation of Ukraine, the Ukrainian Foundation of Start-ups with the support of USAID's "Competitive Economy of Ukraine" [10], focused on developing entrepreneurial skills in and through higher education, is a response to the modern development of flexible innovative business and the growth of selfemployment in the youth segment of the labour market [11], whereby the lack of entrepreneurial skills is considered to be a barrier to student employment opportunities.

The contribution aims to supplement the current discussion on entrepreneurial skills by clarifying the current composition and content thereof, by highlighting global (professional) skills, and by predicting future skills that may affect the profile of the profession and that may need to be included in curricula.

\section{Methodology}

As part of the research, literature was reviewed on the issues of enhancing entrepreneurship in the student environment, the formation of the start-up movement in universities, standards of higher education in Ukraine in specializations in order to identify the entrepreneurial competencies prescribed in them, and research results from international organizations on current and future entrepreneurial skills and competencies.

Basic entrepreneurial skills were presented comprehensively, often in the form of specific disciplines that are offered on Coursera and which meet the needs of current businesses. For example:

H1: Accountancy stimulates the generation of accounting skills, the creation of accounting, financial and tax information, and reporting under state or international standards.

H2: The communication skills of an entrepreneur are developed in practice by discussing a task or problem with two or more people in written or verbal form.

H3: Financial analysis skills are allocation investment opportunities of risk or uncertainty.

H4: Management provides for the formation of the skills needed to develop a company's strategy and coordinate the efforts of its employees.

H5: Marketing as an entrepreneurial skill is the ability to create positive, trusting, long-term relationships with potential and actual customers, allowing enterprises to establish rules and regulations for doing business in the regional and global markets.

H6: Sales as an entrepreneurial skill is focused on an effective system for bringing the company's products and services to the market and conducting transactions with real customers.

Quality comparative analysis (QCA) is not primarily an evaluation technique, the original application lies in comparative political science. QCA analysis seeks to explain individual, unique cases where the investigated 
phenomenon occurred or did not occur in a set of mutually comparable cases. The method is suitable for the evaluation of several dozen cases. It does not evaluate the strength of the dependence between the variables, but identifies the circumstances of how the intervention works. QCA is suitable for testing the theory of change. It is often supplemented by case studies and is also a supporting tool for statistical methods. The analysis indicates the necessary and/or sufficient or irrelevant conditions that (do not) lead to the observed phenomenon. It is also possible to perform the analysis at multiple levels simultaneously, i.e. it is possible to evaluate different and seemingly "unrelated" conditions of the investigated phenomenon at the same time without applying statistical methods.

The main steps of the methodological procedure were:

- determination of the hypotheses based on the theory of change, including the identification of the dependent variable and conditioning factors, i.e. gaps;

- data collection;

- $\quad$ creation of a truth table of the presence/absence of individual variables;

- calculation of the parameters of the individual variables with logical minimization;

- $\quad$ interpretation of the obtained results.

The selection of the variables was based on the practical experience and professional skills of the authors of the contribution, which were subsequently discussed with all stakeholders. For each factor, a hypothesis, respectively an assumption was made, that argues and explains the relationships and contexts of the influence of a factor on the resulting indicator.

\section{Results and Discussion}

The analysis conducted showed that there are gaps in the formation of students' entrepreneurial skills in Ukrainian universities. This is primarily connected to the specific demands from businesses in a rapidly changing world. This is reflected in the Global Skills Index 2020 Report [12], which focuses on the skills that are most important for businesses and high-tech areas, that is, the skills of a modern entrepreneur as well as start-up participants.

The following entrepreneurial skills are currently considered important [13]: creative thinking; leadership; the ability to take risks; adherence to business ethics; as well as business storytelling; computer skills; critical thinking; flexibility; logical thinking; non-verbal communication; planning; working with social media; strategic planning; team building; time management; and trend setting. Oosterbeeket et al. [14], describe the ten most important determinants of successful entrepreneurship. These are: the need for achievement; need for autonomy; need for power; social orientation; self-efficacy; endurance; risk-taking propensity; market awareness; creativity; and flexibility.

The aforementioned key skills of a modern entrepreneur do not give an indication of which disciplines enable the formation of these skills and competencies at university. For example, creative thinking includes the development of emotional intelligence, the ability to understand root problems, the ability to brainstorm, and the ability to build a team. Similarly, adhering to business ethics presupposes a deep knowledge and understanding of business planning, project management, the ability to work independently, consistently, and purposefully. Entrepreneurial competencies are therefore ambiguous and include several personal characteristics, attitudes and skills of a particular person.

Entrepreneurial skills can also viewed in reverse, based on the most important elements of entrepreneurship learning [15]. In this case, a certain combination of knowledge, abilities, skills and competencies, consisting of awareness of the enterprise (start-up), the field of business (business skills in the form of accounting, business planning, etc.) and creativity, shape the effectiveness of entrepreneurial decisions and business in general. This combination of knowledge, skills and competencies makes entrepreneurship learning challenging (see Table 1), whereby the question of the best way to develop an entrepreneurial skills package within the constraints of higher education remains unresolved. 
Table 1. Students' entrepreneurial skills and learning elements

\begin{tabular}{|c|c|c|}
\hline Groups of competencies & Students' entrepreneurial skills & Learning elements \\
\hline $\begin{array}{l}\text { Common entrepreneurial } \\
\text { competencies }\end{array}$ & $\begin{array}{c}\text { To form and evaluate an idea } \\
\text { To see problems as opportunities } \\
\text { To identify key stakeholders } \\
\text { To assess the needs for business development } \\
\text { Emotional intelligence and business ethics }\end{array}$ & $\begin{array}{l}\text { Business planning; } \\
\text { Project management }\end{array}$ \\
\hline $\begin{array}{l}\text { Competencies connected } \\
\text { with management }\end{array}$ & $\begin{array}{l}\text { To know how to build relationships with stakeholders and } \\
\text { manage them }\end{array}$ & $\begin{array}{l}\text { Business storytelling; } \\
\text { Business law; } \\
\text { Team building }\end{array}$ \\
\hline $\begin{array}{l}\text { Competencies connected } \\
\text { with entrepreneurship }\end{array}$ & $\begin{array}{c}\text { Business plan development } \\
\text { Business growth planning } \\
\text { Setting standards and performance criteria } \\
\text { Marketing analysis and sales strategies } \\
\text { Choice of financial strategies } \\
\text { Use of professional counselling skills }\end{array}$ & $\begin{array}{c}\text { Operations management; } \\
\text { Strategic planning; } \\
\text { Accounting, audit, analysis of } \\
\text { activities; } \\
\text { Marketing; } \\
\text { Risk management }\end{array}$ \\
\hline Entrepreneurial values & $\begin{array}{c}\text { Initiative } \\
\text { Willingness to take responsibility } \\
\text { Autonomy } \\
\text { Intuitive decision making with limited information } \\
\text { Ability to interact and persuade } \\
\text { Result orientation } \\
\text { Willingness to take risks }\end{array}$ & $\begin{array}{l}\text { Participation in business } \\
\text { games, hackathons, start-up, } \\
\text { battles }\end{array}$ \\
\hline $\begin{array}{l}\text { Awareness of the } \\
\text { entrepreneurial lifestyle }\end{array}$ & $\begin{array}{l}\text { Understanding the advantages and disadvantages of being } \\
\text { an entrepreneur versus being an employee }\end{array}$ & \\
\hline
\end{tabular}

Source: Authors.

It is the shared opinion of the authors that the presented way of grouping entrepreneurial skills and competencies is archaic. Modern understanding of knowledge, abilities, skills and competencies is associated with their division into hard and soft skills:

Entrepreneurial hard skills [16] consist of those competencies that enable the management of human resources, marketing, production, management and finances.

Entrepreneurial soft skills [17] consist of those competencies that enhance one of 13 dimensions: initiative; seeing and taking advantage of opportunities; perseverance; searching for information; focus on the high level of performance; commitment to the job; orientation towards efficiency; systematic planning; problem-solving; confidence; power of persuasion; influencing strategies; and assertiveness.

Of the entrepreneurial hard skills listed for non-business department students, the production element is the most significant in terms of its influences on the intention to become an entrepreneur [16, 18]. This is because this competence becomes the basis for choosing a professional role in a team with the participation of a student in business games, hackathons, start-up battles, during an internship or practice.

Of the main entrepreneurial soft skills listed for non-business department students, initiative, self-confidence and persistence are the most significant influences on entrepreneurial activity. They have a significant impact on the intention to become an entrepreneur.

Entrepreneurial intent is usually defined as the intention of an individual to start a new business venture [19]. Despite the importance of measuring intent in the entrepreneurial setting, universities are more interested in measuring learning and performance, given that they are expected to measure program learning outcomes [20].

As the entrepreneurial process is not linear, creativity and finding structure in an unstructured process are central [21]. Entrepreneurship is a complex process that lacks linearity of business thinking, which requires students to therefore master uncertain environments [22]. So, educators in entrepreneurship have the task of giving students the necessary skills with which to survive in a fast and rapidly changing environment. The development of entrepreneurial skills can be improved by providing a learning environment in which students interact with real businesses in live projects [23].

In Ukraine, the development of educational programs and curricula is carried out based on the national higher education standards [24]. Within the education system, these should act as the conduit for the development of entrepreneurial competencies in both non-business department students and students of economic and managerial specializations. Currently, 150 national standards of higher education for Bachelor's and Master's degrees in 105 specializations have been developed and implemented. An analysis thereof made it possible to identify common competencies in terms of soft skills (see Table 2). 
Table 2. Students' entrepreneurial soft skills according to the Higher Education Standards of Ukraine

\begin{tabular}{|l|c|c|}
\hline \multicolumn{1}{|c|}{ Level of education } & Students' entrepreneurial soft skills & Learning elements \\
\hline $\begin{array}{l}\text { First level of higher } \\
\text { education } \\
\text { (Bachelor's degree) }\end{array}$ & $\begin{array}{c}\text { Ability to communicate in official and foreign languages } \\
\text { both verbally and in writing } \\
\text { Ability to communicate with representatives of other } \\
\text { professional groups of different levels (with experts from } \\
\text { other fields of knowledge/types of economic activity) } \\
\text { Ability to generate new ideas (creativity); } \\
\text { ability to work in a team } \\
\text { Interpersonal skills }\end{array}$ & $\begin{array}{c}\text { Native and foreign languages } \\
\text { (profession-oriented) }\end{array}$ \\
& $\begin{array}{c}\text { Participation in business } \\
\text { Ability to adapt and act in a new situation } \\
\text { ability to identify, pose and solve problems }\end{array}$ \\
$\begin{array}{l}\text { Second level of higher } \\
\text { education } \\
\text { (Master's degree) }\end{array}$ & $\begin{array}{c}\text { Ability to make informed decisions } \\
\text { Ability to generate new ideas (creativity) } \\
\text { Ability to develop and manage projects } \\
\text { Ability to communicate in a foreign language } \\
\text { The ability to motivate people and move towards a } \\
\text { common goal }\end{array}$ & $\begin{array}{c}\text { Forest } \\
\text { (profession-oriented) }\end{array}$ \\
\hline
\end{tabular}

Source: Authors.

It should be noted that "entrepreneurship" or "self-employment" is not found in the explanatory notes as a field of graduate employment. At the same time, consultancy activities in line with the branch of knowledge and specialization is noted present in $10 \%$ of Bachelor's degree standards and $15 \%$ of Master's degree standards.

Youth Business International (YBI), the global network of expert organizations, has developed four groups of entrepreneurial soft skills (see Table 3) that are currently the most valuable for young entrepreneurs and which need to be developed and strengthened in a changing world [25].

Table 3. YBI entrepreneurial soft skills framework

\begin{tabular}{|c|c|c|}
\hline Skill group & Today's skills & Future skills \\
\hline \multirow{3}{*}{ Intra- and interpersonal skills } & Positive self-concept & $\begin{array}{c}\text { Mindfulness (new) } \\
\text { Self-awareness and self-realization (amplified) }\end{array}$ \\
\hline & Communication skills & $\begin{array}{c}\text { Business storytelling (new) } \\
\text { Negotiating networks, crowds, and movements } \\
\text { (amplified) }\end{array}$ \\
\hline & Social and interpersonal skills & $\begin{array}{c}\text { Working with networks, crowds and movements } \\
\text { (new) } \\
\text { Empathy and compassion (amplified) } \\
\text { Emotional/social intelligence and influence } \\
\text { (amplified) }\end{array}$ \\
\hline \multirow{3}{*}{$\begin{array}{l}\text { Creative and problem-solve } \\
\text { skills }\end{array}$} & $\begin{array}{c}\text { Planning, organization, execution } \\
\text { and management }\end{array}$ & $\begin{array}{c}\text { Adaptive planning and management (new) Time } \\
\text { management (amplified) }\end{array}$ \\
\hline & Higher-order thinking skills & $\begin{array}{c}\text { Systems thinking (new) } \\
\text { Complex problem-solving (amplified) }\end{array}$ \\
\hline & Creativity and innovation & $\begin{array}{c}\text { Co-design (new) } \\
\text { Co-creativity and innovation (amplified) }\end{array}$ \\
\hline \multirow{3}{*}{$\begin{array}{l}\text { Information, opportunity, and } \\
\text { risk management skills }\end{array}$} & $\begin{array}{l}\text { Opportunity seeking, recognition } \\
\text { and assessment }\end{array}$ & Building and managing online reputation (new) \\
\hline & $\begin{array}{c}\text { Information seeking and } \\
\text { management }\end{array}$ & Complex information management (amplified) \\
\hline & $\begin{array}{c}\text { Coping with ambiguity, uncertainty } \\
\text { and risk }\end{array}$ & $\begin{array}{l}\text { Wellness management (new) } \\
\text { VUCA coping skills (amplified) }\end{array}$ \\
\hline \multirow{3}{*}{ Growth mindset skills } & Persistence, tenacity and resilience & Grit (new) \\
\hline & Flexibility and adaptability & Agility (new) \\
\hline & Future orientation & $\begin{array}{c}\text { Active learning skills (new) } \\
\text { Motivation to continuously learn (amplified) }\end{array}$ \\
\hline
\end{tabular}

Source: [25].

It should be noted that modern Ukrainian entrepreneurs are already actively using entrepreneurial soft skills: 
Mindfulness - most entrepreneurs keep accounting records of their activities, form and submit reports to the tax service and other regulatory authorities.

Working with networks, crowds and movements, and building and managing their online reputations. Even before the pandemic, most entrepreneurs built their company websites in order to create an active digital presence, attracting subscribers and delivering valuable content to them. This includes pages on the most popular social networks - Instagram, Facebook, Telegram - for interaction with their clients, for conducting market research, and for promoting or testing new business ideas.

The need for systems thinking is compensated for in the entrepreneurial environment by the growth of the consultancy activities of narrow specialists and the intensification of applied scientific research at universities.

As a result, some entrepreneurial soft skills have been strengthened as skills of today and ceased to be skills of the future. Within this context, when comparing the YBI entrepreneurial soft skills framework with that of the entrepreneurial soft skills required under the Higher Education Standards of Ukraine, it becomes very clear that the latest standards, some of which were only adopted in 2020, are hopelessly outdated and require updating in line with current trends and the challenges of a changing world.

Entrepreneurship education is a complex set of measures that affects all levels of education (including teacher training), all subjects, and all parties involved in the education process: policymakers, education administration, school administrations, teachers, students, neighbouring communities, etc. [26]. This realization makes it necessary to involve all stakeholders in the educational process.

The feasibility and necessity of teaching entrepreneurial skills to non-business department students is justified by Martin Lackéus [27]. He focuses on key entrepreneurial competencies like knowledge, skills and attitudes that affect a person's readiness and ability to become an entrepreneur:

Marketing skills - conducting market research; assessing the marketplace; marketing products and services; power of persuasion; getting people excited about your ideas; dealing with customers; communicating a vision.

Resource skills - creating a business plan; creating a financial plan; obtaining financing; securing access to resources.

Opportunity skills - recognizing and acting on business opportunities and other kinds of opportunities; product/service/concept development skills.

Interpersonal skills - leadership; motivating others; managing people; listening; resolving conflicts; socializing.

Learning skills - active learning; adapting to new situations; coping with uncertainty.

Strategic skills - setting priorities (goal setting) and focusing on goals; defining a vision; developing a strategy; identifying strategic partners.

These entrepreneurial skills can be formed among university students by focusing their activities on long-term teamwork to solve the real problems of external stakeholders. That is, setting complex educational tasks that are multidisciplinary in nature, that require social interaction for their implementation, and that make use of process focused and practice-based learning methods.

\section{Conclusion}

The basic competencies of a manager contribute to the successful performance of the relevant work activity. These competencies are usually assessed according to professional knowledge, such as acquired education and professional skills, which a manager acquires mainly through regular training and sufficient practice. The role of manager in an organization is also shaped by social maturity, which manifests itself through character traits. It is projected in the style of management and management work, in which the manager plays the role of a manager. The manager performs tasks in the usual way, repeatedly so. The individual style of managerial work is shaped by the personality of the manager, but also by the conditions in which the manager works, such as the team. In practice, there are ten typical characteristics a manager should have, namely vision, commitment, openness, integrity, creativity, assertiveness, generosity, modesty, justice, and a sense of humour.

Entrepreneurial skills, knowledge and mindset are crucial factors contributing to the growth of the economy and the benefit of society [28]. The focus in the educational process is to not only help students develop the skills to become fully fledged entrepreneurs but to present a universally applicable skills set.

Currently, the formation of entrepreneurial skills in students needs to focus on the ability to take risks, the ability to quickly adapt to changing environmental conditions, and the ability to interact with stakeholders, including remotely through networks, crowds and movements. These entrepreneurial soft skills should be formed 
at the first level of higher education (Bachelor's degree). With regards to the formation of entrepreneurial hard skills at the Bachelor's degree level, this mainly concerns business plan development and business growth. This includes basic planning, organization, marketing, sales and finance skills. Further entrepreneurial soft skills at the Bachelor's degree level should include business storytelling, and for entrepreneurial hard skills, adaptive planning and management. By focusing on these areas, the education system will support the integration of Bachelor's degree graduates from non-business departments into the job market, not only as employees, but also as entrepreneurs.

For the second level of higher education (Master's degree), analytical skills should be refocused on overcoming resource constraints and maintaining social/community values in a competitive environment. The current emphasis on the awareness of the regulatory aspects of entrepreneurial activity needs to also shift towards creativity, creative thinking, and non-standard management decision-making in order to adapt to the challenges of a changing world.

\section{References}

1. I. Krakovetskaya, A. Dalibozhko, I. Slesarenko, Forming hard and soft skills for university graduates employability enhancement. Proceedings of the 31st International Business Information Management Association Conference, IBIMA 2018: Innovation Management and Education Excellence through Vision 2020. 2454-2466 (2018)

2. A. Dardiri, I. Alfianto, T. Kuncoro, H. Usman, Sugiono, Entrepreneurial leadership for excellent technical and vocational education institutions. World Transactions on Engineering and Technology Education. 16(4), 441-447 (2018)

3. Y. M. L. Malaikosa, N. Ulfatin, N. S. Degeng, Maisyaroh, Curriculum management and learning with creative economics to shape life skills. International Journal of Innovation, Creativity and Change. 12(12), 444-456 (2020)

4. S. Tomy, E. Pardede, An entrepreneurial intention model focusing on higher education. International Journal of Entrepreneurial Behavior \& Research. 26(7), 1423-1447 (2020)

5. J. Turner, G. Mulholland, Enterprise education: Towards a framework for effective engagement with the learners of today. Journal of Management Development. 36(6), 801-816 (2017)

6. C. Rowe, Clarifying the use of competence and competency models in recruitment, assessment and staff development. Industrial and Commercial training. 27(11), 12-17 (1995)

7. A. Gonzi, Competency-based learning: a dubious past-an assured future? In D. Boud, J. Garrick, (Ed.) Understanding learning at work. Londres: Routledge, 180-194 (1999)

8. H. Brandao, J. Borges-Andrade, Causas e efeitos da expressão de competências no trabalho: para entendermelhor a noção de competência [Causes and effects of the expression of skills at work: to better understand the notion of competence]. Revista de Administração Mackenzie. 8(3), 32-49 (2008)

9. Ukrainian Venture Capital \& Private Equity Association. Access to Information, Ukrainian Venture Capital and Private Equity Overview 2019. [online]. Available at: http://uvca.eu/ua/news/investments-intoukrainian-startups-in-2019-overview (2020)

10. Ministry of Education and Science of Ukraine, Access to Information, Presentation of the Entrepreneurial University Initiative. [online]. Available at: https://mon.gov.ua/ua/events/22-veresnya-onlajn-prezentaciyainiciativi-pidpriyemnickij-universitet (2020)

11. L. Gulyayeva, L. Zhuk, Startap-dvizheniye v Ukraine kak innovatsionnaya model' dlya ustoychivogo razvitiya biznesa [Start-up movement in Ukraine as an innovative model for sustainable business development]. Ikonomika na ustoychivoto razvitiye. 2, 21-30 (2016)

12. Coursera. Access to Information, Global Skills Index 2020 [online]. Available at: https://www.coursera.org/gsi (2020)

13. A. Doyle, Essential Skills for Entrepreneurs. Access to Information, The Balance Careers. [online]. Available at: https://www.thebalancecareers.com/list-of-skills-entrepreneurs-need-2062391 (2020)

14. H. Oosterbeek, M. VanPraag, A. Ijsselstein, The impact of entrepreneurship education on entrepreneurship skills and motivation. European Economic Review. 54(3), 442-454 (2010)

15. A. I. Frank, Entrepreneurship and enterprise skills: A missing element of planning education? Planning Education \& Skills. 22, 635-648 (2007) 
16. C. M. Chou, C. H, Shen, H. C. Hsiao, S. C. Chen, A Study on Constructing Entrepreneurial competence indicators for business department students of vocational and technical colleges in Taiwan. World Transactions on Engineering and Technology Education. 8(3), 316-320 (2010)

17. L. M. Spencer, Competence at work: Models for superior performance. New Jersey: John Wiley Sons Inc. (1993)

18. B. P. D. Riyanti, Ch. W. Sandroto, M. T. Warmiyati D.W., Soft Skill Competencies, Hard Skill Competencies, and Intention to Become Entrepreneur of Vocational Graduates. International Research Journal of Business Studies. 9(2), 119-132 (2016)

19. N. Krueger, Entrepreneurial Intentions are Dead: Long Live Entrepreneurial Intentions. In A. Carsrud, M. Brännback (eds). Understanding the Entrepreneurial Mind. International Studies in Entrepreneurship. New York: Springer (2009)

20. N. Mozahem, R. Adlouni, Using Entrepreneurial Self-Efficacy as an Indirect Measure of Entrepreneurial Education. The International Journal of Management Education. In Press. (2020)

21. G. Linton, M. Klinton, University entrepreneurship education: a design thinking approach to learning. Journal of Innovations and Entrepreneurship. 8 (2019)

22. H. M. Neck, P. G. Greene, Entrepreneurship education: Known worlds and new Frontiers. Journal of Small Business Management. 49(1), 55-70 (2011)

23. J. Chang, A. Rieple, Assessing students' entrepreneurial skills development in live projects. Journal of Small Business and Enterprise Development. 20(1), 225-241 (2013)

24. Ministry of Education and Science of Ukraine, Access to Information, Higher Education Standards. [online]. Available at: https://mon.gov.ua/ua/osvita/visha-osvita/naukovo-metodichna-rada-ministerstva-osviti-inauki-ukrayini/zatverdzheni-standarti-vishoyi-osviti (2020)

25. Youth Business International (YBI). Access to Information, Entrepreneurial soft skills for the future: a scoping study. [online]. Available at: https://www.youthbusiness.org/file_uploads/YBISoftSkillsForTheFuture.pdf (2019)

26. V. Bikse, I. Riemere, The Development of Entrepreneurial Competences for Students of Mathematics and the Science Subjects: The Latvian Experience. Procedia - Social and Behavioural Sciences. 82, 511-519 (2013)

27. M. Lackéus, Entrepreneurship in education [online]. Available at: https://www.oecd.org/cfe/leed/BGP_Entrepreneurship-in-Education.pdf (2015)

28. Y. Maaravi, B. Heller, S. Amar, H. Stav, Training techniques for entrepreneurial value creation. Entrepreneurship Education. 3, 215-238 (2020) 